\title{
Uncovering the 2010 Haiti earthquake death toll
}

J. E. Daniell ${ }^{1,2}$, B. Khazai ${ }^{2}$, and F. Wenzel ${ }^{2}$

${ }^{1}$ General Sir John Monash Scholar, The General Sir John Monash Foundation, Level 5, 30 Collins Street, Melbourne, Victoria, 3000, Australia

${ }^{2}$ Center for Disaster Management and Risk Reduction Technology (CEDIM) and Geophysical Institute, Karlsruhe Institute of Technology, Hertzstrasse 16, 76187, Karlsruhe, Germany

Received: 29 April 2013 - Accepted: 6 May 2013 - Published: 15 May 2013

Correspondence to: J. E. Daniell (j.e.daniell@gmail.com)

Published by Copernicus Publications on behalf of the European Geosciences Union.
Uncovering the 2010

Haiti earthquake death toll

J. E. Daniell et al.

Title Page

Abstract

Introduction

Conclusions

References

Tables

Figures

14

I

4

Back

Close

Printer-friendly Version

Interactive Discussion 


\section{Abstract}

Casualties are estimated for the 12 January 2010 earthquake in Haiti using various reports calibrated by observed building damage states from satellite imagery and reconnaissance reports on the ground. By investigating various damage reports, casu5 alty estimates and burial figures, for a one year period from 12 January 2010 until 12 January 2011, there is also strong evidence that the official government figures of 316000 total dead and missing, reported to have been caused by the earthquake, are significantly overestimated. The authors have examined damage and casualties report to arrive at their estimation that the median death toll is less than half of this value 10 ( \pm 137000$)$. The authors show through a study of historical earthquake death tolls, that overestimates of earthquake death tolls occur in many cases, and is not unique to Haiti. As death toll is one of the key elements for determining the amount of aid and reconstruction funds that will be mobilized, scientific means to estimate death tolls should be applied. Studies of international aid in recent natural disasters reveal that large distributions of aid which do not match the respective needs may cause oversupply of help, aggravate corruption and social disruption rather than reduce them, and lead to distrust within the donor community.

\section{Introduction}

A day after the great Haiti earthquake, the country's president, René Préval, speculated that 30000-50 000 people (CNN, 2010) may have died based on Haitian Red Cross and World Health Organization (WHO) estimates - though officials conceded there was no real way to make an estimate amid the chaos in the poorest country in the Western Hemisphere. Nearly three months after the 12 January 2010 Haiti Earthquake, the latest government-released death toll estimates were between 222500 and 300000 (SNGRD, 2010a; USAID, 2010a; Al Jazeera, 2010). The shaking of the Moment Magnitude $\left(M_{\mathrm{w}}\right) 7.0$ earthquake which occurred at a relatively shallow depth $(13 \mathrm{~km})$ was
NHESSD

1, 1913-1942, 2013

\section{Uncovering the 2010 \\ Haiti earthquake death toll}

J. E. Daniell et al.

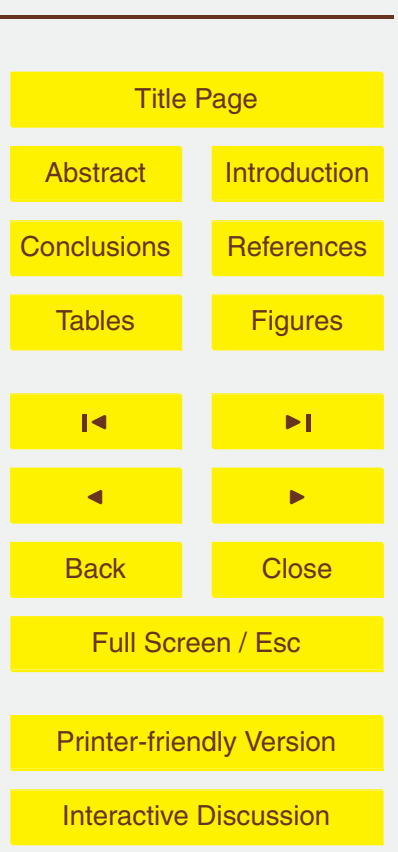


significant and caused widespread destruction of buildings in towns like Léogâne and Carrefour, as well as major destruction within the poorly-constructed and denselypacked Port-au-Prince metropolitan area only $30 \mathrm{~km}$ from the earthquake hypocenter (USGS, 2010a).

5 Several conditions further exacerbated the impact of the earthquake in terms of increased casualties. The non-seismic construction standards and little enforcement of building codes in most cases led to very poor earthquake performance. Unsafe construction practices were so pervasive that they even crossed socio-economic boundaries; poorly constructed cinder block buildings collapsed during the earthquake, as 10 did Port-au-Prince luxury hotels and the United Nations (UN) mission headquarters. Certainly some of the lives lost in the rubble could have been saved if effective urban search-and-rescue teams and emergency medical units were available in the impacted areas within the first few critical hours following the earthquake. In Haiti, disruptions in critical infrastructure (telecommunications, electrical networks, transport facilities and hospitals) and absence of a coordinated response arrangement further undermined the search and rescue effort, and significantly impacted the number of people rescued from the rubble.

Studies of search and rescue efforts after earthquakes indicate that less than $50 \%$ of people buried under collapsed buildings will still be alive two to six hours after entrapment (De Bruycker et al., 1983). Haiti, unlike China where a very strong military response was mobilized within minutes, simply did not have the resources to act quickly, and it took time for foreign aid to arrive. Furthermore, the dense urban environment in Port-au-Prince made it a difficult place for rescue teams to work in once they were there. In China, machines and methods to remove debris, tents and support systems were in place quickly and many decentralized stations were mobilized allowing for relief staff to effectively undertake recovery and rescue.

Given a large-scale urban earthquake and conditions that exacerbated the initial impact of the catastrophic earthquake in Haiti, death toll estimates of up to $6 \%$ of the country's total population (or just under $20 \%$ of the population of Port-au-Prince)
NHESSD

$1,1913-1942,2013$

\section{Uncovering the 2010 \\ Haiti earthquake death toll}

J. E. Daniell et al.

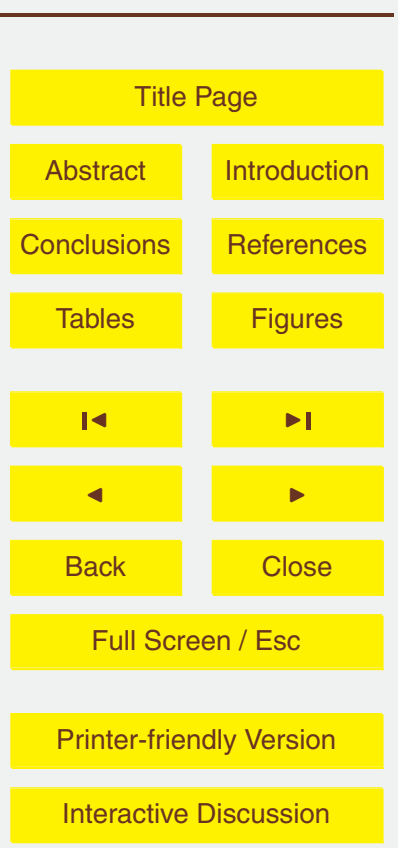


may not seem very surprising. Nevertheless, casualty rates that would be expected from the observed building damages (EC-JRC, 2010a; Eberhard et al., 2010; Rathje et al., 2010) and verified burial statistics (Melissen, 2010) do not correspond with government-released casualty and missing rates, even when accounting for all the 5 aggravating conditions present in Haiti that could lead to increased death tolls.

\section{Methodology}

Given the large range of available data, the following methodology was followed in order to assess the best death toll estimate for the Haiti earthquake of 2010:

1. The damage data estimates of the original damage estimates from the time of the original death tolls were compared to the MTPTC ground survey tagging of buildings.

2. A realistic and justified range of damage data is then created.

3. The death toll ranges of the Haiti government and other source estimates over the time period were compared.

4. Various occupancy assumptions and building losses are compared to the death toll estimates.

5. These are then compared to create an estimate allowing for the range of uncertainty shown in the death toll releases.

By using historical data from every damaging earthquake recorded worldwide, the range of death tolls is then compared to historical estimates with a focus on the range of death toll estimates.

\section{NHESSD}

1, 1913-1942, 2013

\section{Uncovering the 2010}

Haiti earthquake death toll

J. E. Daniell et al.

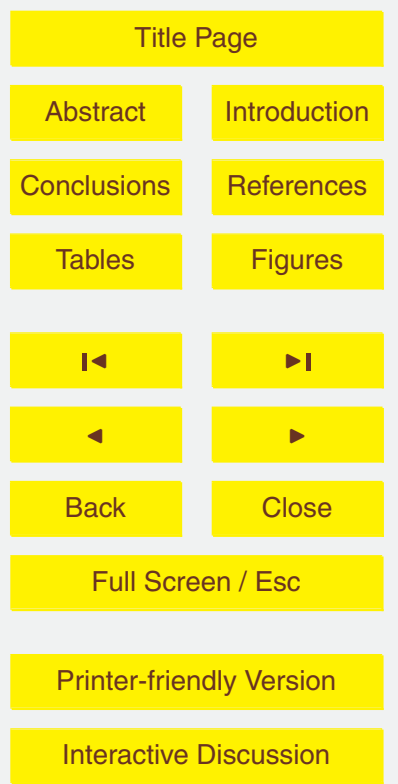




\section{Post-earthquake damage in Haiti}

It has been found through CATDAT, that where secondary effects of earthquakes do not occur, nearly $100 \%$ of deaths are due to building collapse in earthquakes with over 1000 deaths. Thus, it is important to quantify the building damage to gain an insight 5 into the Haiti death toll.

The worldwide CATDAT damaging earthquakes and secondary effects (tsunami, fire, landslides, liquefaction and fault rupture) database was developed to validate, remove discrepancies and expand greatly upon existing global earthquake databases; and to better understand the trends in vulnerability, exposure and possible future impacts of such historical earthquakes (Daniell, 2010a; Daniell et al., 2011). This is further explained in Sect. 5.

As expected, the damage reports that came out after the Haiti earthquake via remote sensing pointed to high-density urban areas such as Port-au-Prince for the greatest observed damage density (EC-JRC, 2010a). The Post Disaster Needs Assessment and

15 Recovery Framework Report (PDNA) combined the findings of a validated building damage assessment, using work from a variety of NGOs, organizations, governments, consortia and companies on the ground. The government also released their own estimates during the death toll estimate stage.

The latest and most accurate survey is that of the ground survey of USAID/OFDA and Miyamoto International for the MTPTC by 554 Haitian Engineers who have tagged 400000 buildings as to habitability (MTPTC, 2011). Of the building stock audited, 80000 of these were tagged red (reconstruction necessary) and around 120000 yellow tagged (indicating work required but safe), $200000+$ buildings have been green tagged.

25 Of the $20 \%$ red tagged buildings, some had completely collapsed, but many remained stable enough for life safety. The $30 \%$ of yellow tagged buildings will be able to be repaired for less than US\$2000. The data that is available currently is for 381000 of these buildings.

NHESSD

1, 1913-1942, 2013

\section{Uncovering the 2010 \\ Haiti earthquake death toll}

J. E. Daniell et al.

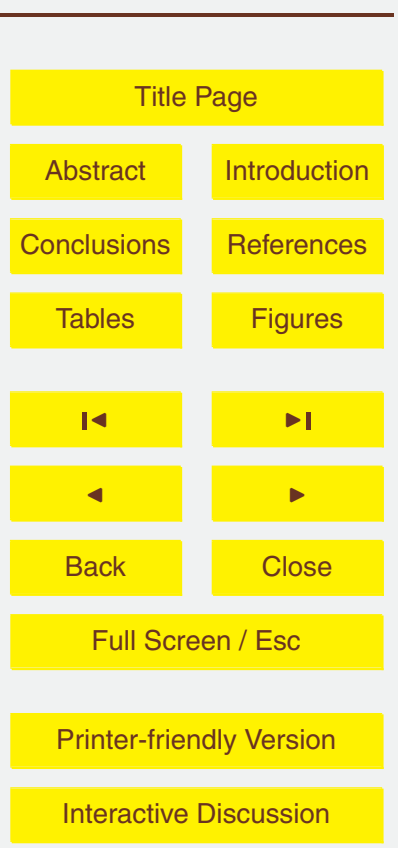


The downtown and commercial buildings had about $25 \%$ destruction rate and $45 \%$ moderate-heavy damage; however, these buildings do not make up a significant percentage of total building floor area (approximately $12 \%$ of Port-au-Prince, $1-3 \%$ in other major centers like Carrefour, Delmas93 and less than $1 \%$ in all other areas) 5 in other earthquake-affected locations in Haiti. Shanty towns and the biggest slum in Port-au-Prince, Cité Soleil, were also reported to have experienced high damage levels ( $15 \%$ destroyed and $20 \%$ moderate-heavy damage). In spite of the extensive damage in these areas, casualties were less due to the use of less vulnerable building methods such as utilizing sheet metal as roofing and one-storey construction (EC-JRC, 2010a). 10 Casualties due to damages in rural areas, such as Jacmel and other parts of Carrefour, Léogâne, Grand-Goâve, Gressier and the Sud-Est provinces were reported to be much less (EC-JRC, 2010a,b; Melissen 2010; SNGRD, 2010b; OCHA, 2010a).

Although it is impossible to convert building damage levels to tagging levels directly, assumptions have been made to undertake this. The red tagged buildings were 15 distributed using all EMS-98, completely destroyed and severely damaged buildings. For the Haiti Government estimate through the last available SNGRD report, 105369 buildings were reported to be destroyed, and 208164 damaged. Of the destroyed, all were assumed to be red. For the damaged buildings however, they include all damage classes - thus, a value of $15 \%$ damaged buildings were added into red buildings, $70 \%$ of these damaged were assumed to be yellow, and $15 \%$ assumed to be green. We assume 400000 buildings as the building count.

Given that the final distribution values of the Miyamoto International damage are not available, as well as the exact values of the Government of Haiti data, we attempt to distribute the building losses of moderate-heavy damage and destroyed buildings over the various locations into red building classes. Given that red tagged buildings by definition are those unsafe, we assume that nearly all deaths occur in these red buildings. They are then adapted with respect to the UNOSAT damage reports.

The observed building damages (from several reports calculated via visual inspection, field studies and satellite imagery), building type distributions and the casualty
NHESSD

1, 1913-1942, 2013

\section{Uncovering the 2010 \\ Haiti earthquake death toll \\ J. E. Daniell et al.}

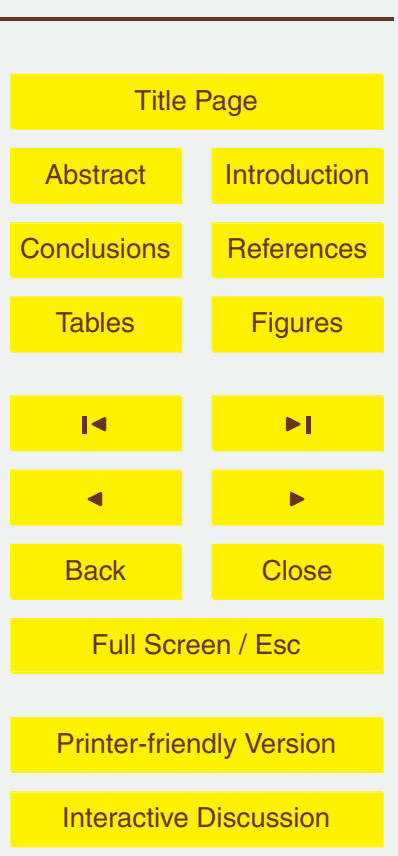


estimates from both the government and aid organizations are presented for the earthquake affected area in Table 1 for the Port-au-Prince area but also all affected towns and cities. The difference in building damage percentages from the PDNA study (covering approximately 3.1 million of the 3.6 million affected population) from those of government are staggering: the government reports of up to 250000 houses and 30000 commercial buildings collapsed (Renois, 2010) seem very large considering a PDNA total damage estimate of less than 25000 buildings destroyed including approx. 3000 commercial buildings (EC-JRC, 2010a). The GEO-CAN effort via remote sensing also shows a large difference from that of the government estimate for Port-au-Prince and other towns as shown in the values of Table 1 (ImageCat et al., 2010).

The building damages can also be compared to the building and demographic census of Haiti (IHSI, 2010a,b) and calibrated against photographic evidence from UNOSAT and other ground-based studies (EC-JRC, 2010a,b; Eberhard et al., 2010; Rathje et al., 2010). These UNOSAT values (ImageCAT et al., 2010) have been investigated by Spence and Saito (2010) using a validation of a small subset of data (approx. 1200 buildings), showing that using Pictometry, a value of up to $50 \%$ more destroyed and heavily damaged buildings could result. In terms of ground observation, a small subset of buildings (124) were investigated for damage class and it was shown with extrapolation it could be expected that the UNOSAT values could be doubled to give a reasonable estimate of destroyed and heavily damaged buildings (Spence and Saito, 2010). The final UNOSAT values however show reasonable correlation with the red tagging of the full ground survey and show that only a $20 \%$ increase in values is expected (Table 2).

It is shown that the Haitian government estimates through SNGRD were about 25 a $70 \%$ overestimate with respect to red tagged building damage.

\section{NHESSD}

$1,1913-1942,2013$

\section{Uncovering the 2010 \\ Haiti earthquake death toll}

J. E. Daniell et al.

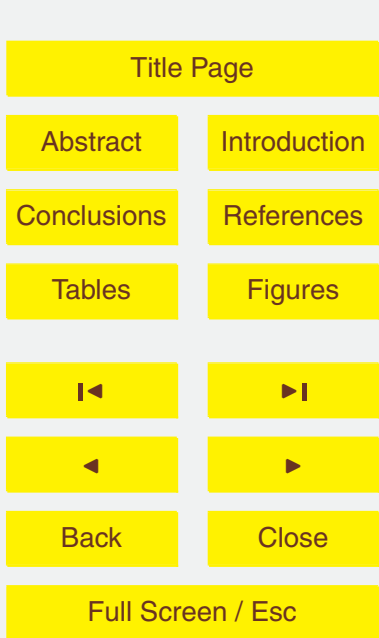

Printer-friendly Version

Interactive Discussion 


\section{Death toll estimates in Haiti}

A lower bound estimate of 52000-92000 deaths was presented by Melissen in 2010 and the highest consistent bound estimate of 316000 was presented by the Prime Minister of the Government of Haiti on 12 January 2011 at the $1 \mathrm{yr}$ anniversary donor 5 conference.

Considering the existing building stock and extent of damage, even when accounting for increased casualties due to factors such as initial injury severity, effective search and rescue, and fade-away time due to delays in extrication and transport to medical facilities, there are several other factors as to why the released higher death tolls may be unrealistic apart from the building damage overestimation by the Haitian government:

1. despite being ill-equipped to handle the rescue of victims, the use of community involvement in rescue cannot be ignored and studies have shown that over $90 \%$ of lightly trapped victims still alive are rescued by people at the scene of collapse (Krimgold, 1989);

2. casualties and the degree of entombment by collapsed structures are correlated with building material and building height (Schweier et al., 2006), and the singlestorey buildings and lighter buildings which make up most of the urban building stock in Haiti (IHSI, 2010a, b) should produce fewer casualties;

3. the earthquake luckily occurred at 4.53 p.m. when many people were outside and travelling from work or school to home and/or outside playing and talking. Thus, a good proportion of the population of Haiti in both urban and rural areas were likely able to survive through the earthquake, even if their houses in some cases were reduced to rubble.

On the contrary, it is noted that:

1. some proportion of deaths would occur in injured rescued people even given community involvement in the absence of medical aid, so this could slightly increase the death toll.
NHESSD

1, 1913-1942, 2013

\section{Uncovering the 2010 \\ Haiti earthquake death toll}

J. E. Daniell et al.

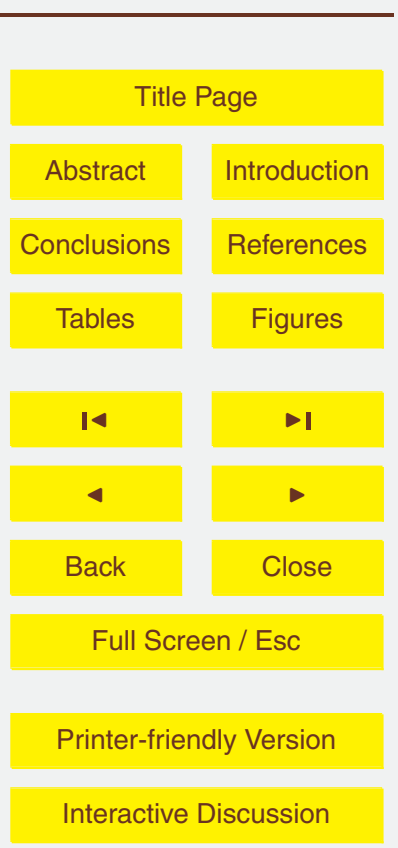


2. In addition, the single-storey buildings sometimes do have concrete slab roofs contributing to increased deaths, and also there would be higher death tolls in multi-storey buildings.

For these reasons, it was decided to delve deeper into the possible anomalies between 5 the death toll from external analyses and those of the government of Haiti (222570 or 316000). Government-released death toll estimates, as well as those given by news reports and aid organizations, were examined since the earthquake hit on 12 January 2010 (Fig. 1). These figures are mainly from Marie-Laurence Lassegue, Haiti's Culture and Communications Minister; René Préval, Haiti's President; and official government press communiqués via the SNGRD (The National Risk and Disaster Management Agency). In the initial days following the earthquake, government estimates of potential fatalities varied from at least 100000 (Jean Max Bellerive, Haitian Prime Minister, CNN, 2010a) to 500000 deaths (Youri Latortue, a leading Haitian Senator, CBS, 2010).

The initial government reports were downscaled after the release of a Haitian Red 15 Cross and Pan-American Health Organization (PAHO) reports of potential death tolls of between 40000 to 50000 (CBS, 2010; PAHO, 2010). The first "official" government estimate from the SNGRD (based on estimates of buried bodies) came one week after the earthquake on 17 January 2010 and reported fatalities of 65000-75000 (with 250000 injured and over 1 million homeless, USAID, 2010b; SNGRD, 2010c). By 21 January, 20 however, the SNGRD death toll estimates increased to 111481 (a rise of 36000 from the previous day, SNGRD, 2010c,d) but stayed fairly constant with only slight changes until 5 February (SNGRD, 2010e). At this point, the death toll for the town of Tabarre was at 7000 .

Interestingly, on 6 February the SNGRD report (SNGRD, 2010f) increased both the 25 death toll and injury estimates by the same value (approximately 100000 ) to 212069 deaths and 300572 injuries. This may not be unrelated to the reports of death tolls by other government officials, such as estimates of 150000 fatalities by Haiti's Public Works Department (Centre Nationale des Equipments) on 23 January (SNGRD, 2010f; Cave, 2010), reports from President Préval on 27 January of 170000 fatalities (AFP,

NHESSD

1, 1913-1942, 2013

\section{Uncovering the 2010 \\ Haiti earthquake death toll \\ J. E. Daniell et al.}

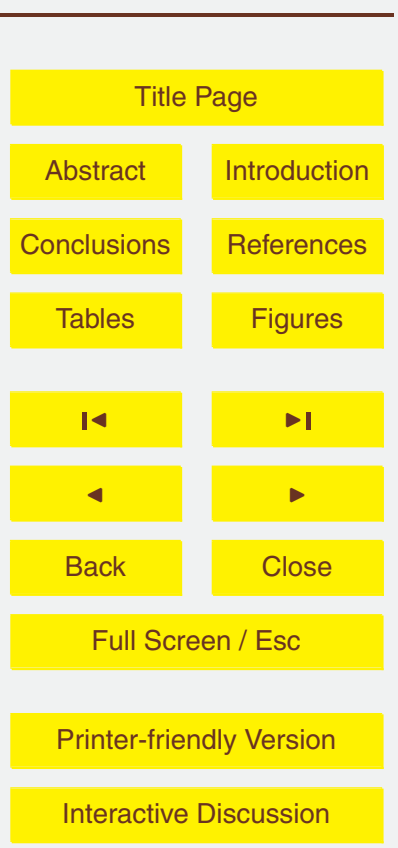


2010) and a death toll announced by Prime Minister Jean-Max Bellerive of 200000 people on 3 February (USAID, 2010c). The government death toll reports continued to rise sharply from 230000 deaths on 10 February by Marie-Laurence Lassegue (Bajak et al., 2010) to 300000 deaths on 21 February by René Préval (Al Jazeera, 2010). The 5 SNGRD casualty estimates remained at approximately 223000 deaths from 21 February 2010 (SNGRD, 2010g) to 5 April 2010, where the death toll for the town of Tabarre had reduced 70 times, to 100 .

Whatever the official death toll, by this time, according to data from cemetery officials in the main cemetery of Port-au-Prince, only 18000 bodies had been buried 10 (Melissen, 2010), as compared to 89000 buried bodies in the main cemetery quoted by Jean-Yves Jason, the Port-au-Prince mayor (Beauchemin, 2010). An independent investigation into the reported death tolls by Hans Jaap Melissen from Radio Netherlands Worldwide claimed that as of 23 February, an estimate of between 52000 and 92000 deaths was the most accurate estimate (Table 3). There is a striking difference of 15131500 casualties between the unexplained Haiti government (SNGRD) estimates of 223469 and that of the figures by Radio Netherlands Worldwide. The Melissen (2010) range also accounted for cremated, mass graves, suicides, those never found and alternatively buried deaths.

Since then, at the $1 \mathrm{yr}$ anniversary meeting of the Haiti Earthquake in which dig20 nitaries like former US President Bill Clinton were at, the Prime Minister Jean-Max Bellerive announced a total of 316000 deaths. This is a total of 93000 more deaths since the 1 April 2010, thus accounting for 327 bodies found or measured every day since then, if the original Haitian government death toll is to be used.

During analysis of historic death tolls through the use of CATDAT (Daniell, 20032013), it can be seen that many initial death tolls can be multiplied by 3 to approximate the final death toll. This would make approximately 135000 to 150000 , using the initial $\mathrm{PAHO}$ and UN estimates.

Above, the range of estimates can be seen in Fig. 1. If we correlate these estimates with building damage and other parameters, then a casualty range can be created.

\section{NHESSD}

1, 1913-1942, 2013

\section{Uncovering the 2010 \\ Haiti earthquake death toll \\ J. E. Daniell et al.}

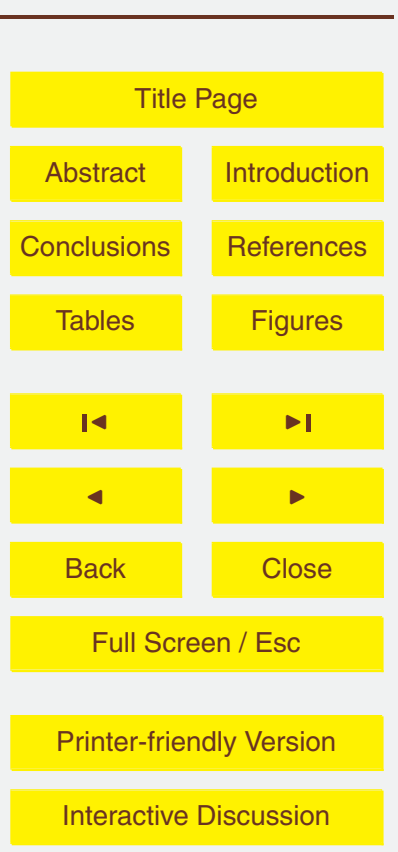


A top-down and bottom-up approach can be used. It can be assumed that the errors in death counts are associated also with double-counting, and the fact officials were overwhelmed by the extent of the disaster.

Given the number of bodies needed to be found since 1 April, and the historic over5 estimate of Renois quoting 280000 buildings destroyed, it can be assumed that the value of 316000 deaths is an aberration. Instead we correlate the value of 222570 (+869 missing) deaths to the building damage associated with the Government of Haiti as a first estimate (136 593 buildings red-tagged).

In a more qualitative bottom-up approach, it is the opinion of the authors, using 10 damage data, that the loss estimate via other death methods such as cremation was closer to 20 000. In addition, death tolls in Port-au-Prince area (Port-au-Prince, Delmas, Petionville) should be estimated to be around 70000 rather than 35000 using higher population density and destruction rates than in other locations (Melissen, 2010). If approximately 40000 people were under the rubble instead of the 30000 detailed by

found using the initial Melissen death tolls as a basis.

The final step in the process is then using the bottom up approach and top down approach in order to work out the overestimate. We assume that the rescue and relief components are in both of these estimates, as they are both from the end of February.

20 The actual value of red-tagged houses in Haiti was 80000 . A conservative assumption would be that the values are a maximum of $18 \%$ underestimated by using the original January values of UNOSAT.

Choosing building parameters as the difference between the two estimates, and using a sliding scale from the 136593 red-tagged buildings assumed by the Haiti Government, where towns under 500 deaths are kept constant (apart from Grand-Goave), a value of 127464 deaths results. We can assume two other boundaries using no damaged buildings in the red-tag, and $25 \%$ of buildings in red-tag. This gives a boundary of 111271 to 164124 deaths.
NHESSD

1, 1913-1942, 2013

\section{Uncovering the 2010 \\ Haiti earthquake death toll}

J. E. Daniell et al.

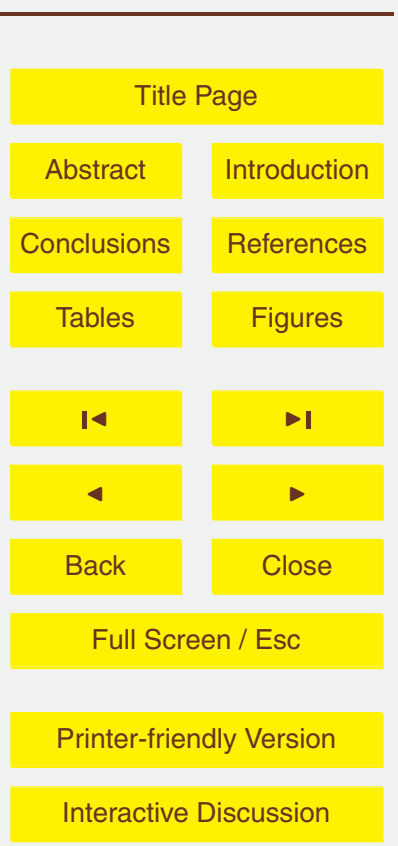


In addition we can add 30000 deaths, due to the possible value of found bodies since 28 February 2010 as a found body count since and also for an increased number of people dying due to their injuries since then. This gives a boundary of 126209 to 186157 deaths.

5 A logic tree approach will now be used to calculate the reasonable range of death tolls in Haiti as shown in Table 4. We also include a normalized version of Renois using the 316000 deaths stated but normalizing against comments of 225000-280 000 destroyed buildings. This gives a range of 90286 to 112356 deaths.

The weighting of the Haiti government statement of 316000 deaths, was so low due 10 to the historic error in their destroyed buildings statement and the fact that 327 bodies would have to have been pulled from the debris everyday since 1 April 2010, even when quoted at 220 000-230 000 in late October. For Port-au-Prince this would add up to around 211000 deaths in this commune alone, and considering the 170423 injured in this commune also, would add up to $42 \%$ of the pre-earthquake population, dead or 15 injured.

The Haiti government statement adjusting for their error in destroyed buildings was also given a low weighting due to the fact that the death toll and destroyed building count were so high compared with the actual values by Miyamoto International, that no degree of confidence could be given to such estimates.

Concurrently, the general rule of thumb is simply a trends analysis based on many different earthquakes, and given the difference in historic estimate ranges, this is also given a low weighting.

It was decided that both the Melissen death toll and the Haiti death toll are equally plausible when not looking at building counts and thus, these were both given equal 25 weighting.

The bottom up approach uses Melissen as a basis, increasing the death toll for parameters where the authors believe this was underestimated, having now a year more data than Melissen who conducted his death toll as of 22 February 2010.

\section{NHESSD}

1, 1913-1942, 2013

\section{Uncovering the 2010 \\ Haiti earthquake death toll}

J. E. Daniell et al.

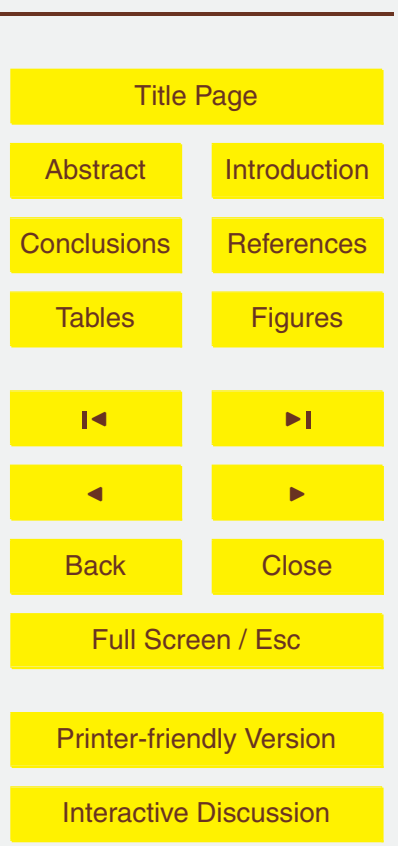


However, the top down approach is by far the best, as it uses the Haiti government detailed death toll for each commune and also the Miyamoto International actual building count as a basis, simply adjusting for the error in building count in the SNGRD reports.

5 The highest ranking was given to the actual death count of the SNGRD, and as no increase has been given apart from the statements this is assumed the best starting point. Thus the top-down approach was given a large percentage of the weighting. The weighting is applied via expert opinion however, with additional expert input the results would be slightly different.

10 Thus, the Haiti death toll is more likely to be 136933 , with a range of 121843 to 167082 dead (Table 4).

\section{The historical difficulties with death toll counts}

Over 22000 sources of information have been utilised since 2003 to present data from over 12400 damaging earthquakes historically, with over 7200 earthquakes since 151900 examined and validated before insertion into the CATDAT Damaging Earthquakes database (Daniell et al., 2011). Since 1900, there have been over 2000 fatal earthquakes worldwide and over 3000 casualty-bearing earthquakes. Each validated earthquake includes seismological information, secondary effects (social, economic and type), building damage (levels, important infrastructure etc.), ranges of social losses

to account for varying sources (deaths, injuries, homeless and affected) and ranges of economic losses (direct, indirect, aid contribution and insurance details). Much other economic and population analysis is also included in the database, as well as socioeconomic vulnerability trends and normalisation analysis with automatic updating via earthquake-report.com (Daniell et al., 2012).

25

Through history using CATDAT, there have been many other discrepancies of earthquake death counts which occurred in the early period following a disaster, either underestimates due to governments trying to limit panic and reduce blame (Turkmenistan

\section{NHESSD}

1, 1913-1942, 2013

\section{Uncovering the 2010 \\ Haiti earthquake death toll}

J. E. Daniell et al.

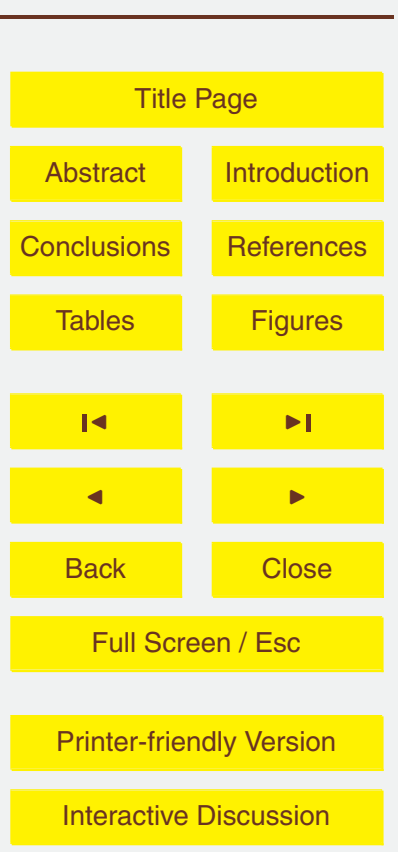


1948, Romania 1977) or overestimates (China 1927, Tajikistan 1949, Chile 1960 and Tangshan 1976) due to sheer enormity of the unexpected impact of earthquakes on the government and government agencies themselves, or a simple inability to calculate the death count, or a need to evoke aid (Daniell, 2010b; Ramirez et al., 2005).

5 A selection of these is shown in Table 5 below. Early casualty estimates after natural disasters are typically not very reliable as they are based on guesswork of casualties in affected neighborhoods, and the widespread infrastructure damage makes it difficult to count bodies (Alexander, 1996, 1993, 1985). Nevertheless, the death tolls along with the number of injured and homeless people establish the scale of the disaster and 10 are critical in establishing the basis of the immediate and reconstruction aid appeal (Cavallo et al., 2010).

In Fig. 2 below, 147 earthquakes with an accepted death toll of 1000 persons or more according to the median CATDAT accepted death toll are presented on the $x$-axis. This value represents the most likely death toll when looking at all literature values with each of these earthquakes. Shown on the y-axis is the upper bound (diamond) and lower bound (square) literature value (with removal of obvious errors) from various global sources. Where there is not much variability, the upper and lower bound value should lie on the middle black line. Where there is a deemed overestimated death toll in literature sources the earthquake appears as a diamond above the accepted median line. Where there is a deemed underestimated death toll in literature sources the earthquake appears as a square below the accepted median line (Daniell et al., 2011). Earthquakes can have a wide range of death toll estimates so in some cases, such as the Shemakha 1902 earthquake, both the upper and lower estimate can be deemed as over- and underestimates on a true death toll. A death toll as low as 86 (NGDC, 2010) and as high as 20000 (London Times, 1902), with a CATDAT accepted median death toll of 2000 results. The Xining earthquake of 1927 is another such earthquake with a range of between 40900 (Gu et al., 1989) and 200000 (EM-DAT).

Estimates by the UN's Office for Coordinating Humanitarian Affairs (OCHA), the organization that is responsible for a consolidated appeal that pulls together the needs
NHESSD

$1,1913-1942,2013$

\section{Uncovering the 2010 \\ Haiti earthquake death toll \\ J. E. Daniell et al.}

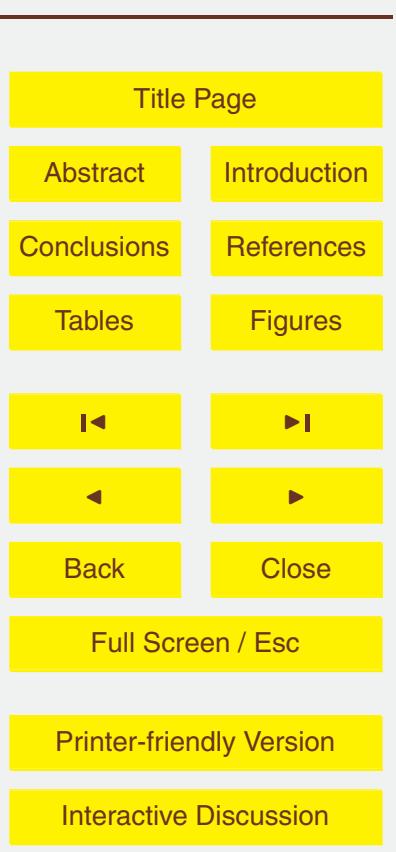


identified by all agencies, are often higher than the local government's as the UN tries to account for regions that have not yet been assessed on the ground by using satellite footage of the wreckage and prior demographic information (Lapados, 2010). Even without such projections, UN numbers are often higher because they err on the side 5 of overestimation to ensure an adequate relief response. This also usually includes a certain amount of aid to reduce disease outbreak. In the case of Haiti, contaminating drinking water sources contributed to the outbreak with an estimated $1000+$ deaths.

As yet, UN/OCHA has used the unexplained estimates of the SNGRD and other government representatives from 16 January onwards. More concerning is perhaps 10 the precise use of unverified casualty estimates in determining the reconstruction aid. The IADB calculated a bottom line of US $\$ 7200$ million (2009 dollars) for a death toll of 200000 and US\$8100 million for a death toll of 250000 in direct economic damages after the Haiti earthquake (Cavallo et al., 2010). The IADB calculations based on death toll estimates are useful for putting the importance of casualty estimates into perspective as a parameter for ultimately determining the basis of the reconstruction funds. The exaggerated mortality figures were also picked up by media outlets, most of which do not have the resources to verify the casualty estimates independently. Studies of mass-media content analysis (Adames, 1986) have found that the three most important factors (accounting for over $60 \%$ of the variation out of 16 factors) that explain US media attention devoted to a natural disaster were: (1) cultural proximity and social interest (i.e. number of US tourists); (2) estimated disaster deaths (modified by a logarithmic scale); and (3) geographical proximity (i.e. distance from New York City). When these factors come together, as in the case of Haiti, they can lead to a so-called "telegenic" effect which has the potential to lead to an outpouring of immediate altruistic giving in the aftermath of an event.

Certainly, even a fraction of the reported casualties constitutes a large human tragedy and undeniably a country like Haiti is in "need of all the help it can get". Yet, it can be argued that more aid is not always "too much of a good thing", and in cases where flow of aid does not match needs and capacities, it may amplify existingproblems

\section{NHESSD}

1, 1913-1942, 2013

\section{Uncovering the 2010 \\ Haiti earthquake death toll \\ J. E. Daniell et al.}

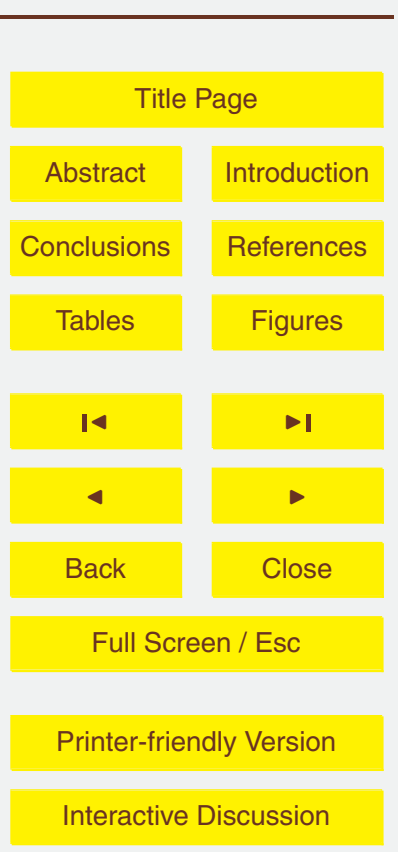


of the most vulnerable populations. For example, the 2004 Indian Ocean Tsunami $\$ 14000$ million aid which surpassed the total estimated cost of damages by about $30 \%$ was found to "exceed the absorption capacity of an overstretched humanitarian industry" (Ville de Goyet et al., 2010). In this case, outpouring of disaster donations has 5 been found to have such adverse impacts as promotion of funding decisions based on media and political pressure rather than actual needs or capacity, competition among aid agencies and disincentives for them to pool resources and information, proliferation of inexperienced NGOs and actors working outside their area of expertise, and weakening of humanitarian impartiality.

10 In the initial period following a disaster, the abundance of supplies cluttering infrastructure vital to delivering aid, further aggravate the incapacity to absorb aid. Many of these supplies have not been requested and are not useful or of first priority to cover the needs of an emergency. In addition, they compromise the efficient reception, storage, classification, control and distribution of these supplies, consuming relief workers' scarce time and resources. There have already been reports of unneeded and unsolicited donations creating bottlenecks at Haiti's strained airport (Freschi, 2010). These differences between the physical and community vulnerability of a disaster may aggravate the physical many times over (Daniell et al, 2010a).

Finally, soaring funding levels and pressure to spend, combined with reduced finan20 cial controls and quick turn-over in staff, provide fertile ground for corruption in emergency procurement which ultimately diverts aid from those who need it most (Cremer, 1998). The risk of corruption is probably higher in critical emergency situations if the general level of corruption in the given country is considered a significant problem (Schultz and Søreide, 2008). Transparency International, which ranks countries according to their perceived level of corruption, has ranked Haiti consistently as one of the 10 most corrupt nations in the world (Transparency International, 2009). The poor local and national governance and debt policies of Haiti, as well as the inability of the aid sector to efficiently absorb the outpouring of aid, can lead to increased vulnerability if the donor aid amount and structure are not matched to present the actual conditions

\section{NHESSD}

1, 1913-1942, 2013

\section{Uncovering the 2010 \\ Haiti earthquake death toll \\ J. E. Daniell et al.}

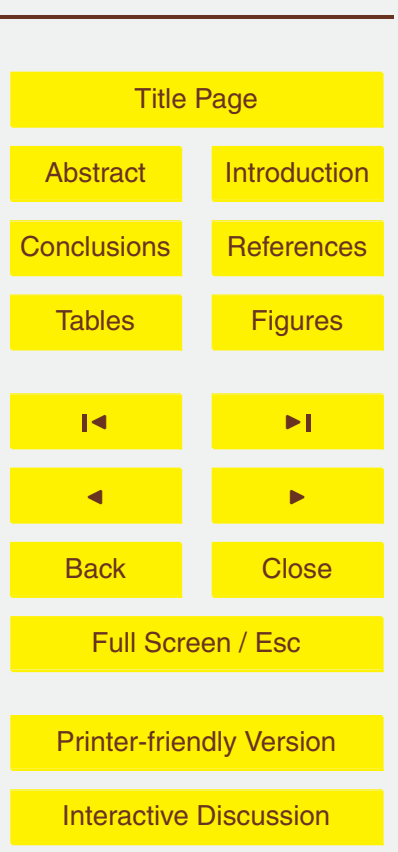


and real needs of the affected population. Although it is known that corruption is difficult to control, it is able to be discouraged and by enhancing the response and plan for aiding a country, enhancing development and creating better living standards, corruption can be reduced.

\section{Conclusions}

Haiti had a 2009 GDP (Nominal) of $\$ 6390$ million and a GDP (Nominal PPP) of approximately $\$ 11500$ million, with a population below the poverty line of $80 \%$ and still \$1000 million in foreign debt even after a \$1200 million reduction through the International Monetary Fund (IMF, 2009). It is one of the 25 poorest countries in the world (IMF, 2010; World Bank, 2010). With a total economic loss (direct and indirect) approaching $70 \%$ of GDP (PPP) (Daniell et al. 2010b) or even more (121\% of Nominal GDP according to the estimate of $\$ 7754$ million of damage, CEPAL, 2010), the 12 January 2010 earthquake will have a significant impact on Haiti for the years to come. There is no question that Haiti requires aid, and no one wants to delay life-saving interventions to conduct a study, but making decisions based on political or media pressure rather than comprehensive survey of the needs leads to waste (Freschi, 2010). Casualty data following the 12 January 2010 earthquake in Haiti from many different sources were used and calibrated by observed building damage states from satellite imagery and reconnaissance reports to arrive at the most realistic estimate of death tolls. A method-

ology based on a logic tree approach for estimating death toll for the Haiti earthquake has been proposed. While death toll is not the only parameter determining the scale of a disaster, it is often used as a key factor for determining the amount of aid and reconstruction funds that will be mobilized in the initial period of a disaster. There will never be a perfect casualty estimate, but a reasonable estimate, not based on sensationalist claims and incomplete information, is required at least by those agencies such as OCHA tasked with overall coordination of aid. The death toll of the Haiti earthquake will never be known, but the value of between 122000 and 167000 seems the
NHESSD

1, 1913-1942, 2013

\section{Uncovering the 2010 \\ Haiti earthquake death toll}

J. E. Daniell et al.

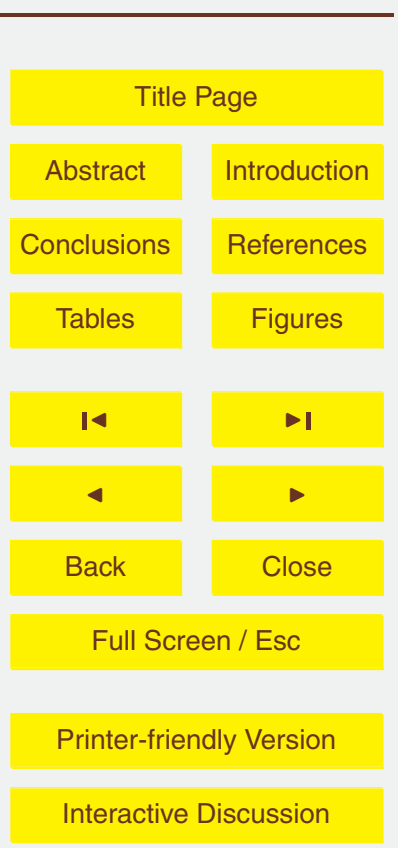


most reasonable estimate, with a preferred value lying somewhere around 137000 deaths. This will ultimately serve in better mitigating the impact of natural disasters on the poor by ensuring that international aid commitments are better matched with solutions to the limited aid-absorptive capacity in disaster-affected countries. Also, in 5 the light of increasing allegations of financial impropriety and mismanagement, greater transparency and accountability on the part of governments in reporting needs and allocation of funds they have received are now a necessity.

Acknowledgements. This paper has been written as part of the development of the author's $\mathrm{PhD}$, funded by the General Sir John Monash Foundation via the Australian Government and 10 also thanks to CEDIM and Karlsruhe Institute of Technology.

The service charges for this open access publication have been covered by a Research Centre of the Helmholtz Association.

\section{References}

ACT International: Appeal - Bam Earthquake Relief and Rehabilitation MEIN-41, ReliefWeb, 17 February 2004.

Adames, W.: Whose Lives count? TV coverage of natural disasters, J. Communication, 36, 113-122, 1986.

AFP (Agence France Presse): Haiti - 170000 cadavres ont été ramassés, selon René Préval (Haiti- 170000 bodies have been collected, according to Réne Préval), Le Monde News, 27 January 2010.

Alexander, D. E.: Death and injury in earthquakes, Disasters, 9, 57-60, 1985.

Alexander, D. E.: Natural Disasters, UCL Press, London and Chapman \& Hall, New York, 1993.

Alexander, D. E.: The health effects of earthquakes in the mid-1990s, Disasters, 20, 231-247, 1996.

Al Jazeera News Americas (2010), Haiti death toll may reach 300000 , Al Jazeera News Americas, 22 February 2010.

\section{NHESSD}

1, 1913-1942, 2013

\section{Uncovering the 2010 \\ Haiti earthquake death toll}

J. E. Daniell et al.

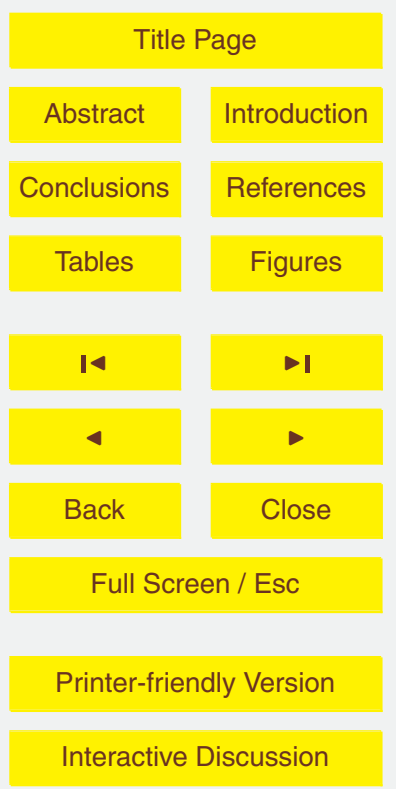


Bajak, F., Dodds, P., Jordans, F., and Klapper, B.: Haiti gives conflicting counts for quake death toll, Japan Today, 10 February 2010.

Bath, M.: Introduction to Seismology, Birkhauser Verlag, Basel, Switzerland, 1973.

Beauchemin, E.: Le maire de port-au-prince conteste le nombre de morts (The mayor of Portau-Prince contests the death toll), Radio Netherlands Worldwide, 25 February 2010.

Cavallo, E. A., Powell, A., and Becerra, O.: Estimating the direct economic damage of the earthquake in Haiti, IDB Working Paper Series \#IDP-WP-163, IDB, 2010.

Cave, D.: More than 150000 Have Been Buried, Haiti Says, New York Times, 23 January 2010.

CBS: Red Cross: Haiti quake deaths as high as 50K, CBS News, 14 January 2010.

10 CEPAL: Principal Results of the informed Post-Disaster Needs Assessment for Haiti, CEPAL Report, 7 July 2010.

CNN: Haiti appeals for aid; official fears 100000 dead after earthquake, CNN News, 13 January 2010.

Cremer, G.: On the problem of misuse in emergency aid, Journal of Humanitarian Assistance, 1998.

Daniell, J. E.: The CATDAT Damaging Earthquakes Database, searchable integrated historical global catastrophe database, Digital Database, updates v0.0 to latest update v5.18, 20032013.

Daniell, J. E.: The CATDAT Damaging Earthquakes Database, in: Proceedings of AEES 2010 Conference, Paper No. 6, Perth, Australia, 26-28 November, 2010a.

Daniell, J. E.: The Socio-economic damage of historical earthquakes and their secondary effects on the Asia-Pacific region infrastructure, in: 5th Civil Engineering Conference in the Asian Region and Australasian Structural Engineering Conference 2010, Paper No. 431, The Engineers Australia, Sydney, Australia, 2010b.

Daniell, J. E. and Love, D.: The Socio-economic impact of historic australian earthquakes, in: Proceedings of AEES 2010 Conference, Paper No. 8, Perth, Australia, 26-28 November, 2010.

Daniell, J. E., Daniell, K. A., Daniell, T. M., and Khazai, B.: A country level physical and community risk index in the Asia-Pacific region for earthquakes and floods, in: 5th Civil Engineering Conference in the Asian Region and Australasian Structural Engineering Conference 2010, Paper No. 392, The Engineers Australia, Sydney, Australia, $2010 a$.

NHESSD

1, 1913-1942, 2013

\section{Uncovering the 2010 \\ Haiti earthquake death toll}

J. E. Daniell et al.

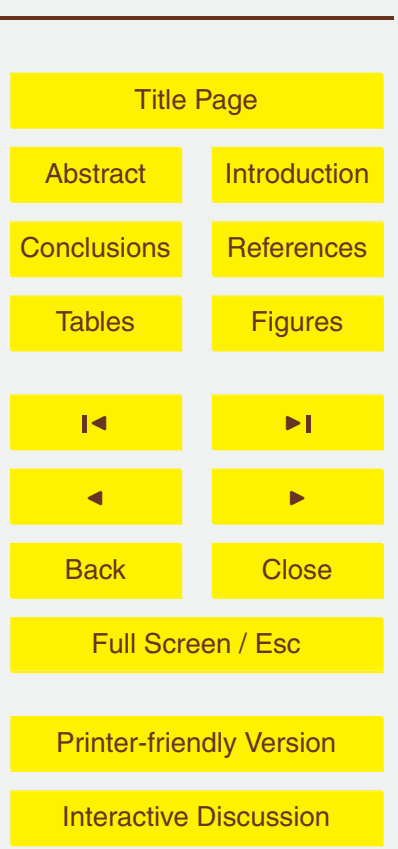


Daniell, J. E., Wenzel, F., and Khazai, B.: The cost of historic earthquakes today - economic analysis since 1900 through the use of CATDAT, in: Proceedings of AEES 2010 Conference, Paper No. 7, Perth, Australia, 2010b.

Daniell, J. E., Khazai, B., Wenzel, F., and Vervaeck, A.: The CATDAT damaging earthquakes 5 database, Nat. Hazards Earth Syst. Sci., 11, 2235-2251, doi:10.5194/nhess-11-2235-2011, 2011.

Daniell, J. E., Wenzel, F., and Vervaeck, A.: The Normalisation of socio-economic losses from historic worldwide earthquakes from 1900 to 2012, 15th WCEE, Lisbon, Portugal, Paper No. 2027, 2012.

10 De Bruycker, M., Greco, D., Annino, I., Stazi, M. A., de Ruggiero, N., Triassi, M., de Kettenis, Y. P., and Lechat, M. F.: The 1980 earthquake in southern Italy: rescue of trapped victims and mortality, Bull. WHO, 2, 34-47, 1983.

de Ville de Goyet, C. and Morinière, L.: The role of needs assessment in the tsunami response, Tsunami Evaluation Coalition, Call No. 885, 2006.

Eberhard, M. O., Baldridge, S., Marshall, J., Mooney, W., and Rix, G. J.: The Mw 7.0 Haiti Earthquake of January 12, 2010: USGS/EERI Advance Reconnaissance Team: Team Report v1.1, US Geological Survey Open-File Report 2010-1048, 2010.

EC, JRC, UNOSAT, World Bank GFDRR and UNITAR: Haiti Building Damage Atlas (as of 26 January 2010), Version 2, March 2010a.

EM-DAT: Emergency Management Database, CRED, Catholic University of Louvain, available at: www.emdat.be, last access: 15 January 2010.

European Commission (EC), Joint Research Centre (JRC), United Nations Institute for Training and Research (UNITAR), Operational Satellite Applications Programme (UNOSAT), World Bank Global Facility for Disaster Reduction and Recovery (GFDRR) and Centre National d'Information Géo-Spatial (CNIGS): Building Damage Assessment Report - Haiti Earthquake 12 January 2010 - Post Disaster Needs Assessment and Recovery Framework (PDNA), Version 3.0, 11 March 2010b.

Evans, S. G., Roberts, N. J., Ischuk, A., Delaney, K. B., Morozova, G. S., and Tutubalina, O.: Landslides triggered by the 1949 Khait earthquake, Tajikistan and associated loss of life,

$30 \quad$ Eng. Geol., 109, 195-212, 2009.

Freschi, L.: Getting Humanitarian Relief Right, Forbes Commentary, 18 January 2010.

Gu, G., Lin., T., and Shi, Z.: Catalogue of Chinese Earthquakes (1831 B. C.-1969 A. D.), Science Press, Beijing, China, 1989.

\section{NHESSD}

1, 1913-1942, 2013

\section{Uncovering the 2010 \\ Haiti earthquake death toll}

J. E. Daniell et al.

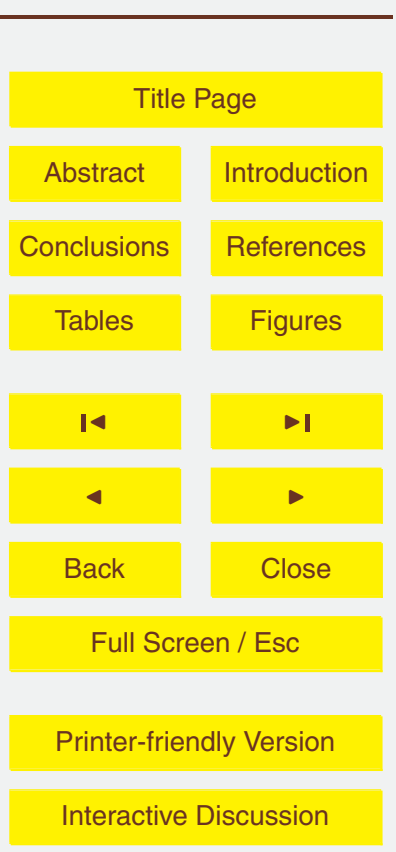


IHSI (Haitian Institute of Statistics and Informatics): Présentation Générale des Résultats de RGPH-03: Batiments (General Presentation of the results of the Population and Housing Census of 2003: Buildings), Report RGPH03-b, 2010a.

IHSI: Enquête sur les conditions de vie en Haiti - ECVH01 (Inquiry into the living conditions in Haiti, Report ECVH01, 2010b.

ImageCat and EERI: Remote Sensing and the GEO-CAN Community: Lessons from Haiti and Recommendations for the Future, Workshop Report, 30 June 2010.

IMF: World Economic Outlook Database: Statistical Annex to World Economic Outlook Report, available at: www.imf.org/external/pubs/ft/weo/2009/01/weodata/index.aspx, accessed

101 April 2009.

Krimgold, F.: Search and rescue, Earthq. Spectra, 23, 136-149, 1989.

Lapados, J.: How Will They Count the Dead in Haiti? - The grim statistics of natural disasters, Slate Magazine, 13 January 2010.

London Times: Seismic Disturbances Recommence - Number of Killed Now Placed at 5,000,

$15 \quad$ New York Times, 21 February, 1902.

Melissen, H.-J.: Haiti quake death toll well under 100 000, Radio Netherlands Worldwide, 23 February 2010.

Morris, C.: Morris's Story of the Great Earthquake of 1908 and other Historic Disasters, Press Publishing Company, Philadelphia, USA, 1909.

20 MTPTC: KML files showing evaluation of red, yellow and green tagged buildings from the MTPTC Building Habitability survey since 11 March 2010, Ministry of Public Works, Transport and Communications, available at: http://www.mtptc.gouv.ht/index.php?c=bteb_index, accessed 7 March 2011, 2009.

MunichRe: Globe of Natural Disasters, MRNATHAN DVD, Munich Reinsurance Company, 2009.

NGDC/NOAA: Significant Earthquakes Database, 2010 online searchable catalogue - based on Dunbar, P. K., Lockridge, P. A. and Whiteside, L. S. (1992), Catalog of Significant Earthquakes, 2150 B. C.-1991 A. D. Including Quantitative Casualties and Damage, NOAA National Geophysical Data Center Report SE-49, Boulder, Colorado, 2010.

30 OCHA: Haiti - Internal Displacement and Population Figures (as of February 28, 2010), OCHA, 4 March 2010.
NHESSD

1, 1913-1942, 2013

\section{Uncovering the 2010 \\ Haiti earthquake death toll}

J. E. Daniell et al.

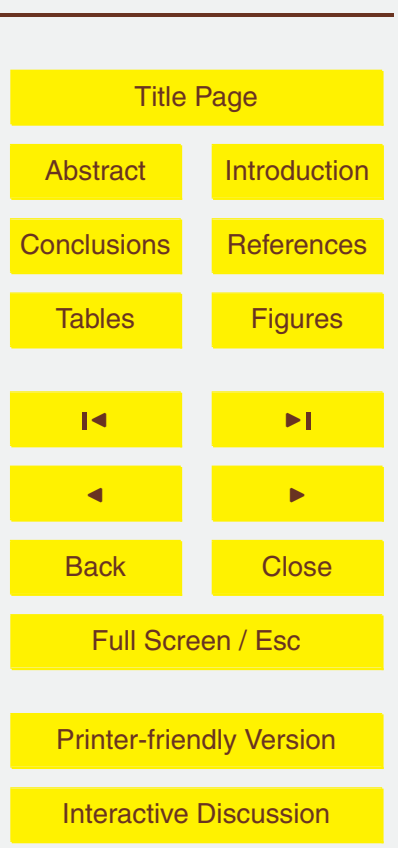


Office for the Coordination of Humanitarian Affairs (OCHA): United Nations Disaster Assessment Coordination (UNDAC) Mission following the Bam Earthquake of 26 December 2003, UNDAC Mission Report, 2004.

PAGER-CAT: PAGER-CAT Earthquake Catalog, 2008. As described in Allen, T. I., Marano, K., 5 Earle, P. S., and Wald, D. J.: PAGER-CAT: A composite earthquake catalog for calibrating global fatality models, Seism. Res. Lett., 80, 50-56, 2009.

PAHO (Pan-American Health Organisation): Emergency Operations Center Situation Report \#3, Haiti Earthquake, PAHO, 15 January 2010.

Ramirez, M. and Peek-Asa, C.: Epidemiology of traumatic injuries from earthquakes, Epidemiol.

10 Rev., 27, 47-55, 2005.

Rathje, E., Bachhuber, J., Cox, B., French, J., Green, R., Olson, S., Rix, G., Wells, D., Suncar, O., Harp, E., Mann, P., and Koehler, R.: Geotechnical Engineering Reconnaissance of the 2010 Haiti Earthquake, GEER Association Report No. GEER-021, Version 1, 22 February 2010.

15 Renois, C.: Haitians angry over slow aid, The Age, 5 February 2010.

Schultz, J. and Søreide, T.: Corruption in emergency aid procurement, Disasters, 32, 516-536, 2008.

Schweier, C. and Markus, M.: Classification of collapsed buildings for fast damage and loss assessment, B. Earthq. Eng., 4, 177-192, 2006.

SNGRD (Système national de gestion des risques et des désastres - National Risk and Disaster Management Agency): Bulletin d'Information du Gouvernement Haïtien - 8 au 12 mars 2010 (Information Bulletin of the Haitian Government spanning 8th-12th March), SNGRD Situation Report 16, 2010a.

SNGRD: Bilan des dégâts \#6 24 Janvier 2010 (Damage Assessment \#6 24 January 2010), SNGRD Report, 2010b.

SNGRD: 20 Janvier 20102 p.m. Informations pour la Presse (20 January 20102 p.m., Press Information from SNGRD), SNGRD Report, 2010c.

SNGRD: Bilan des dégâts \# 21 Janvier 2010 (Damage Assessment \# 21 January 2010), SNGRD Report, 2010d.

30 SNGRD: Damage Assessment in SNGRD Information Bulletin of 3 February 2010 (from French), SNGRD Report, 2010e.

SNGRD: Situation Report No. 11 - 6th February 2010, SNGRD Report, 2010 f.

SNGRD: SNGRD Situation Report \#13 of 15-21 February 2010, SNGRD Report, 2010g.

\section{NHESSD}

1, 1913-1942, 2013

\section{Uncovering the 2010 \\ Haiti earthquake death toll}

J. E. Daniell et al.

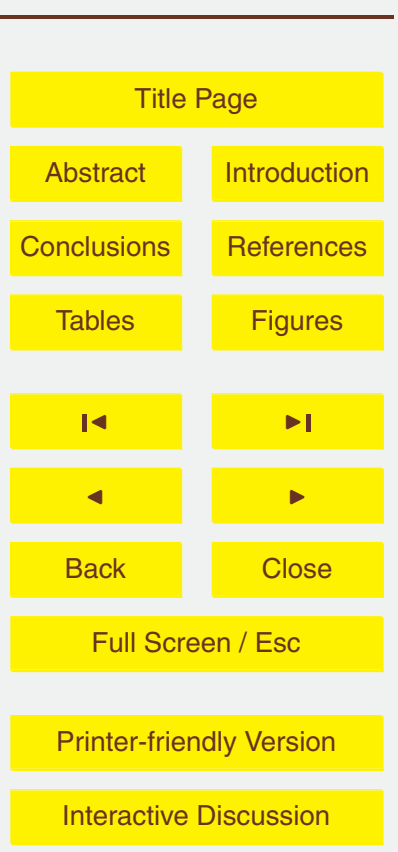


South China Morning Post: Hebei Provincial CCP Committee, Hong Kong, South China Morning Post, 5 January (repeated in London Times, 6 January, p. 1), 1977.

Transparency International: Global Corruption Report 2009 - Corruption Perceptions Index GCR-2009, 2009.

5 UNDP (United Nations Development Programme): Human Development Report 2009 - Overcoming Barriers: Human mobility and development, Report HDR 2009-EN, 2009.

USAID: USAID Haiti - Earthquake Fact Sheet \#47, Fiscal Year (FY) 2010, 26 March 2010, Bureau for Democracy, Conflict, and Humanitarian Assistance (DCHA) and Office of US Foreign Disaster Assistance (OFDA), 2010a.

USAID: USAID Haiti - Earthquake Fact Sheet \#5, Fiscal Year (FY) 2010, 17 January 2010, DCHA and OFDA, 2010b.

USAID: USAID Haiti - Earthquake Fact Sheet \#23, Fiscal Year (FY) 2010, 4 February 2010, DCHA and OFDA, 2010c.

USAID: USAID/OFDA Haiti One-Year Shelter and Settlements Overview - 12 January 2011, DCHA and OFDA, 2011.

USGS (United States Geological Survey): Magnitude 7.0 - Haiti Region 2010 January 12 21:53:10 UTC, USGS Earthquake Hazards Program, available at: http://earthquake.usgs. gov/earthquakes/eqinthenews/2010/us2010rja6/, last access: 13 January 2010a.

USGS: Historic World Earthquakes, available at: http://earthquake.usgs.gov/earthquakes/ world/historical_country.php, last access 7 July 2010b.

World Bank: World Development Indicators Database, available at: siteresources.worldbank. org/DATASTATISTICS/Resources/GDP_PPP.pdf, last access: 15 September 2009.

Yablokov, A.: The tragedy of Khait: a national disaster in Tajikistan, Mt. Res. Dev., 21, 91-93, 2009.

Yong, C., Tsoi, K.-L., Feibi, C., Zhenhuan, G., Qijia, Z., and Zhangli, C. (Eds.): The Great Tangshan Earthquake of 1976: An Anatomy of Disaster, Pergamon Press, Oxford, 153 pp., 1988.

Zahrai, S. M. and Heidarzadeh, M.: Seismic performance of existing buildings during the 2003 Bam earthquake, 13th WCEE, Vancouver, Paper No. 1715, 2004.

\section{NHESSD}

$1,1913-1942,2013$

\section{Uncovering the 2010 \\ Haiti earthquake death toll}

J. E. Daniell et al.

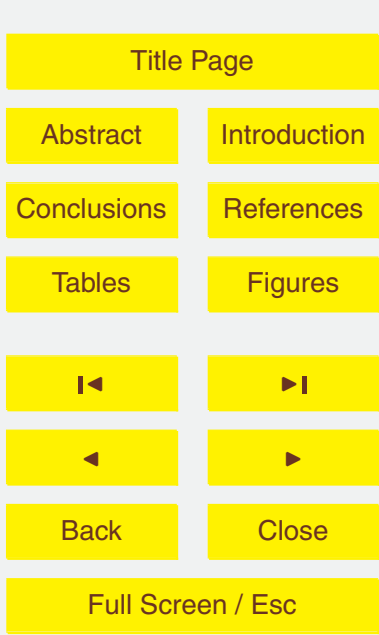

Printer-friendly Version

Interactive Discussion 


\section{NHESSD}

1, 1913-1942, 2013

\section{Uncovering the 2010}

Haiti earthquake death toll

J. E. Daniell et al.

Table 1. Building tagging (red, yellow, green) using various methods for the 2010 Haiti Earthquake (SNGRD, 2010a; MTPTC, 2011).

\begin{tabular}{|c|c|c|c|c|}
\hline & $\begin{array}{l}\text { UNOSAT } \\
\text { (Main } 11 \text { cities) }\end{array}$ & $\begin{array}{l}\text { Govt. Haiti } \\
\text { (Renois) }\end{array}$ & $\begin{array}{l}\text { Govt. Haiti } \\
\text { (SNGRD) }\end{array}$ & $\begin{array}{l}\text { MTMPC/Miyamoto } \\
\text { - USAID Proper }\end{array}$ \\
\hline Approx. Red & $59073(20 \%)$ & 280000 (70\%) & $136593(34 \%)$ & $77548(20 \%)$ \\
\hline Approx. Yellow & 51946 (17\%) & Not given & 145715 (37\%) & 98310 (26\%) \\
\hline Approx. Green & $188238(63 \%)$ & Not given & $117692(29 \%)$ & $205382(54 \%)$ \\
\hline Total & 299257 (100\%) & 400000 (100\%) & $400000(100 \%)$ & 381240 (100\%) \\
\hline
\end{tabular}

Title Page

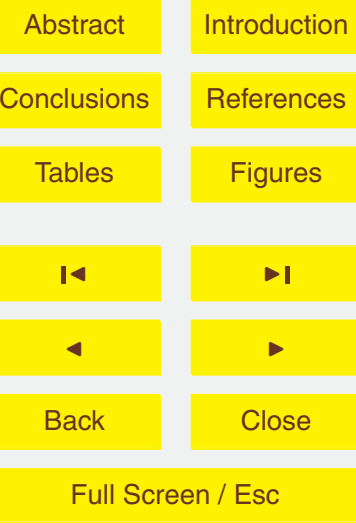

Printer-friendly Version

Interactive Discussion 


\section{NHESSD}

$1,1913-1942,2013$

Table 2. Damage reports adapted over the main cities via red-tagged buildings in the 2010 Haiti earthquake (EC-JRC, 2010a; OCHA, 2010a; MTPTC, 2011).

\begin{tabular}{|c|c|c|c|c|}
\hline Area & Composition & $\begin{array}{l}\text { Damage Reports } \\
\text { (UNOSAT/UNITAR/ } \\
\text { JRC-EC PDNA/ } \\
\text { GEO-CAN) }\end{array}$ & $\begin{array}{l}\text { Damage Reports } \\
\text { from Haiti } \\
\text { Government, } \\
\text { SNGRD etc. }\end{array}$ & $\begin{array}{l}\text { Final assess- } \\
\text { ment of } \\
\text { MTMPC-USAID } \\
\text { - assumed }\end{array}$ \\
\hline Carrefour & Mod. density urban & $8673(16 \%)$ & $978 ?$ & $11669(19 \%)$ \\
\hline Cite Soleil & High density urban & $1561(16 \%)$ & 3292 (34 \%) & $2169(18 \%)$ \\
\hline Croix-des-Bouquets & Mod. density urban & Included in other towns & 3438 & $7772(15 \%)$ \\
\hline Delmas 93 & High density urban & $7826(17 \%)$ & $16506(36 \%)$ & $10123(17 \%)$ \\
\hline Grand-Goave & Mostly rural & $689(19 \%)$ & 4950 & $816(23 \%)$ \\
\hline Gressier & Low density urban & $854(16 \%)$ & 5139 & 2655 (39\%) \\
\hline Jacmel & Mostly rural & $1999(15 \%)$ & 4036 & $814(21 \%)$ \\
\hline Léogâne & Urban-rural mixed & 8205 (21\%) & 17305 (44 \%) & $8249(51 \%)$ \\
\hline Pétionville & Low density urban & $2933(18 \%)$ & $6186(39 \%)$ & $5606(11 \%)$ \\
\hline Petit-Goave & Urban-rural mixed & $277(21 \%)-$ urban & 12638 - total & Unk. \\
\hline Port-au-Prince & High density urban & $25159(24 \%)$ & $53063(50 \%)$ & 25202 (29\%) \\
\hline Tabarre & Urban-rural mixed & $897(15 \%)-$ urban & 453 & $2320(11 \%)$ \\
\hline $\begin{array}{l}\text { Other towns } \\
\text { in Ouest and } \\
\text { other provinces }\end{array}$ & $\begin{array}{l}\text { Mainly rural and } \\
\text { low dens. urban }\end{array}$ & $\begin{array}{l}\text { Unknown but assume } \\
10 \% \text { of } 100000\end{array}$ & 24000 & $\begin{array}{l}\text { Assumed } 10000 \\
\text { in other areas } \\
\text { out of the } 100000\end{array}$ \\
\hline Total & & $69073(17.3 \%)$ & $136593(34.1 \%)$ & $\begin{array}{l}77548(20 \%) \\
\text { w/o other towns }\end{array}$ \\
\hline
\end{tabular}

\section{Uncovering the 2010 Haiti earthquake death toll}

J. E. Daniell et al.

Title Page

\begin{tabular}{|c|c|}
\hline Abstract & Introduction \\
\hline Conclusions & References \\
\hline Tables & Figures \\
\hline I4 & \\
\hline 4 & \\
\hline Back & Close \\
\hline Full Screen / Esc \\
\hline
\end{tabular}

Printer-friendly Version

Interactive Discussion 
Table 3. Death tolls for the 2010 Haiti earthquake as spatially disaggregated from various sources (SNGRD, 2010a; Melissen, 2010; Govt. Haiti, 2011).

\begin{tabular}{|c|c|c|c|c|}
\hline Area & $\begin{array}{l}\text { Population } \\
\text { (mid-2009) }\end{array}$ & $\begin{array}{l}\text { Melissen (2010) } \\
\text { Death Count including } \\
\text { all death forms } \\
\text { (i.e. buried, entombed, } \\
\text { cremated etc.) }\end{array}$ & $\begin{array}{l}\text { Haiti Government } \\
\text { Death Count } \\
\text { including all } \\
\text { death forms } \\
\text { (28 Feb 2010) }\end{array}$ & $\begin{array}{l}\text { Pre-regression } \\
\text { Melissen (2010) } \\
\text { using distributed } \\
\text { values of other death } \\
\text { counts and those } \\
\text { under rubble etc. }\end{array}$ \\
\hline Carrefour & 465019 & 4000 in Carrefour cemetery & 12300 & 6993 \\
\hline Cite Soleil & 241055 & Included in Port-au-Prince & 249 & 249 \\
\hline Croix-des-Bouquets & 227012 & Included in 10000 & 614 & 614 \\
\hline Delmas93 & 359451 & $\begin{array}{l}\text { Approx. } 7000 \text { in Titanyen } \\
\text { and other cemeteries. }\end{array}$ & 38636 & 12238 \\
\hline Grand-Goave & 124135 & 18 & 259 & 259 \\
\hline Gressier & 33152 & 292 & 860 & 860 \\
\hline Jacmel & 170289 & 400 & 389 & 389 \\
\hline Léogâne & 181709 & $\begin{array}{l}3364 \text { with a possibility of } \\
\text { up to } 5000\end{array}$ & 3364 & 3364 \\
\hline Pétionville & 342694 & $\begin{array}{l}\text { Approx. } 3000 \text { in Titanyen } \\
\text { and other cemeteries }\end{array}$ & 16302 & 5244 \\
\hline Petit-Goave & 157296 & 1077 & 1318 & 1077 \\
\hline Port-au-Prince & 897859 & $\begin{array}{l}\text { Main Cemetery: } 18000 \text {, } \\
\text { Others including Titanyen: } \\
17000\end{array}$ & 148772 & 61191 \\
\hline Tabarre & 118477 & Included in 10000 & $\begin{array}{l}100 \text { (down } \\
\text { from } 7000)\end{array}$ & 100 \\
\hline $\begin{array}{l}\text { Other towns in Ouest } \\
\text { and other provinces }\end{array}$ & & Unknown & 633 & 633 \\
\hline Distributed across all & & $\begin{array}{l}30000 \text { underneath rubble } \\
\text { and other death methods, } \\
10000 \text { in other towns } \\
\text { and other forms of death }\end{array}$ & & \\
\hline Total & & $52000-92000$ & 223439 (inc. missing) & 92000 \\
\hline
\end{tabular}

NHESSD

1, 1913-1942, 2013

\section{Uncovering the 2010 Haiti earthquake death toll}

J. E. Daniell et al.

Title Page

\begin{tabular}{|c|c|}
\hline Abstract & Introduction \\
\hline Conclusions & References \\
\hline Tables & Figures \\
\hline I4 & \\
\hline & \\
\hline Back & \\
\hline Full Screen / Esc \\
\hline Printer-friendly Version \\
\hline Interactive Discussion
\end{tabular}




\section{NHESSD}

1, 1913-1942, 2013

\section{Uncovering the 2010 Haiti earthquake death toll}

Table 4. Logic tree weighting for the final Haiti 2010 death toll estimate between the various discussed methods.

\begin{tabular}{lllll}
\hline Death Toll Method & Lower & Median & Upper & Weighting (\%) \\
\hline Melissen (2010) & 52000 & 82000 & 92000 & 5 \\
Haiti Govt. (SNGRD) (until 11 Jan 2011) & 222570 & 223469 & 230000 & 5 \\
Haiti Govt. Statement (12 Jan 2011) & 316000 & 316000 & 316000 & 0.5 \\
Bottom-up Approach & 138000 & 147000 & 162000 & 15 \\
General rule of thumb & 135000 & 142500 & 150000 & 2 \\
Top-down Approach on Haiti Govt. & 111271 & 127464 & 164124 & 50 \\
Top-down Approach on Haiti Govt. +30 000 bodies & 126209 & 144575 & 186157 & 20 \\
Haiti Govt. Statement adjusted for building error & 90286 & 101321 & 112356 & 2.5 \\
\hline Haiti Death Toll & 121842 & 136933 & 167082 & 100 \\
\hline
\end{tabular}

J. E. Daniell et al.

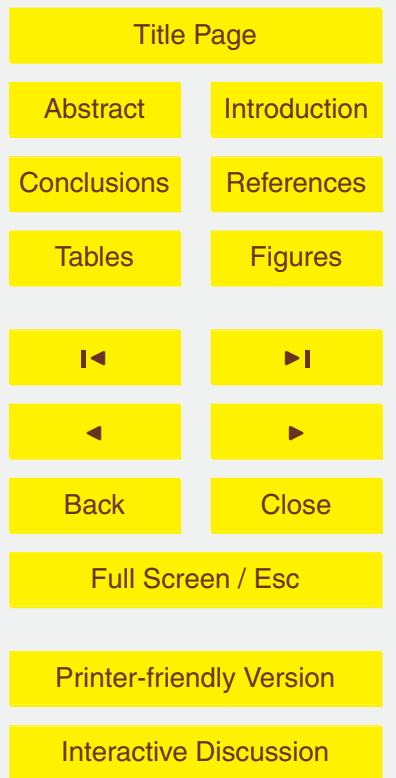




\section{NHESSD}

1, 1913-1942, 2013

\section{Uncovering the 2010 \\ Haiti earthquake death toll}

Table 5. Some historical overestimates of earthquake loss after 1900 via CATDAT v5.18.

\begin{tabular}{|c|c|c|c|}
\hline Earthquake, Country, Year & $\begin{array}{l}\text { Upper or initial estimate } \\
\text { of deaths (combined) }\end{array}$ & $\begin{array}{l}\text { CATDAT } \\
\text { Preferred death toll range }\end{array}$ & Reason for difference \\
\hline Messina, Italy, 1908 & $150000-300000$ (Morris, 1909) & $\begin{array}{l}85926(80000-90000) \\
\text { (MRNATHAN, 2009, } \\
\text { Daniell, 2010a) }\end{array}$ & News reports, scale of disaster. \\
\hline Xining, China, 1927 & 200000 (Bath 1973, EM-DAT) & $\begin{array}{l}40912(40900-45000) \\
\text { (Gu et al., 1989) }\end{array}$ & $\begin{array}{l}\text { Historical confusion } \\
\text { with } 1920 \text { Haiyuan earthquake }\end{array}$ \\
\hline Khait, Tajikistan, 1949 & 28000 (Yablokov, 2001) & $\begin{array}{l}12000 \text { (7200-18000) } \\
\text { (Evans et al., 2009) }\end{array}$ & $\begin{array}{l}\text { Difficult to ascertain } \\
\text { due to landslide and remoteness }\end{array}$ \\
\hline Temuco-Valdivia, Chile, 1960 & $\begin{array}{l}6000-10000 \text { (press reports) } \\
\text { or } 7231 \text { (EM-DAT) }\end{array}$ & $\begin{array}{l}\text { 1655-2231 } \\
\text { (USGS, 2010b) }\end{array}$ & $\begin{array}{l}\text { Initial scale of disaster, } \\
\text { media reporting, errors in } \\
\text { current databases }\end{array}$ \\
\hline Tangshan, China, 1976 & $\begin{array}{l}655237 \text { (initial govt reports } \\
\text { - South China Post, 1977) }\end{array}$ & $\begin{array}{l}242419(240000-255000) \\
\text { (Yong et al., 1989) }\end{array}$ & Initial scale of disaster \\
\hline Izmit, Turkey 1999 & $\begin{array}{l}40000 \text { Bodybags ordered (Govt.), } \\
45000 \text { (Marza, 2004) }\end{array}$ & $\begin{array}{l}17434(17127-20000) \\
\text { (Erdik, 2000) }\end{array}$ & Initial scale of disaster \\
\hline Bam, Iran, 2003 & $\begin{array}{l}41000-50000 \text { (ACT International, } \\
2004 \text {, Zahrai et al., 2004) }\end{array}$ & $\begin{array}{l}26796(25000-30000) \\
\text { (UNDAC, 2004) }\end{array}$ & $\begin{array}{l}\text { Initial scale of disaster, } \\
\text { miscalculation }\end{array}$ \\
\hline
\end{tabular}

J. E. Daniell et al.

Title Page

\begin{tabular}{|c|c|}
\hline Abstract & Introduction \\
\hline Conclusions & References \\
\hline Tables & Figures \\
\hline I4 & \\
\hline Back & Close \\
\hline Full Screen / Esc \\
\hline Printer-friendly Version \\
\hline Interactive Discussion
\end{tabular}




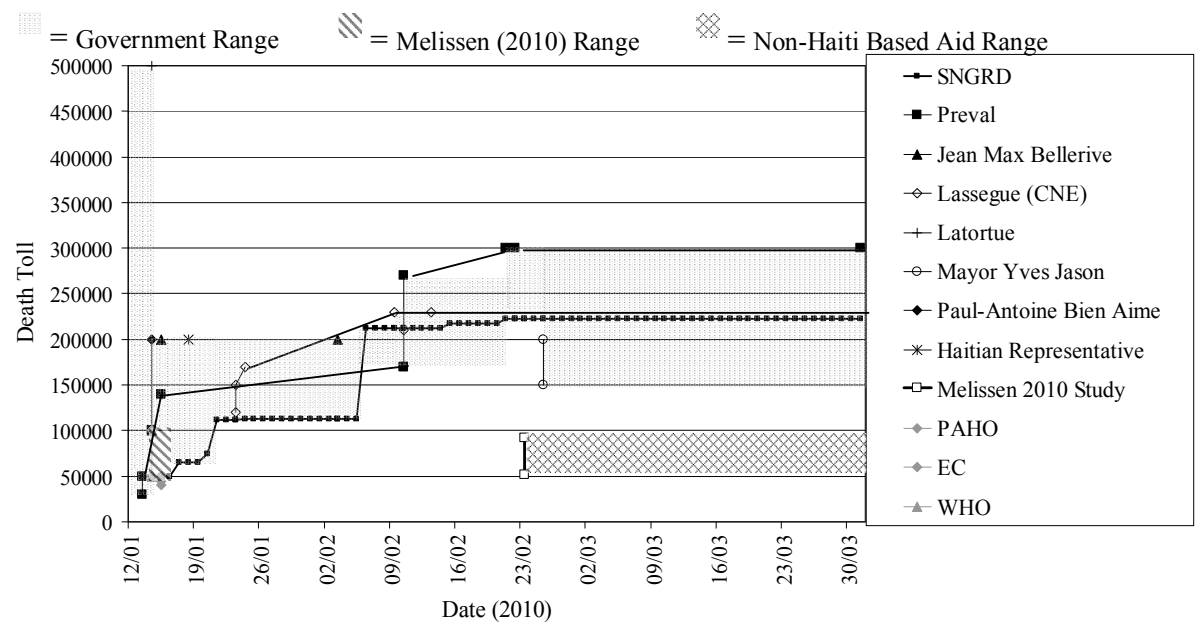

Fig. 1. Haiti death toll estimates from various sources showing the temporal evolution (12 January 2010-1 April 2010).

\section{NHESSD}

1, 1913-1942, 2013

Uncovering the 2010

Haiti earthquake death toll

J. E. Daniell et al.

Title Page

\begin{tabular}{|c|c|}
\hline Abstract & Introduction \\
\hline Conclusions & References \\
\hline Tables & Figures \\
\hline I4 & \\
\hline & \\
\hline Back & Close \\
\hline Full Screen / Esc \\
\hline
\end{tabular}

Printer-friendly Version

Interactive Discussion 


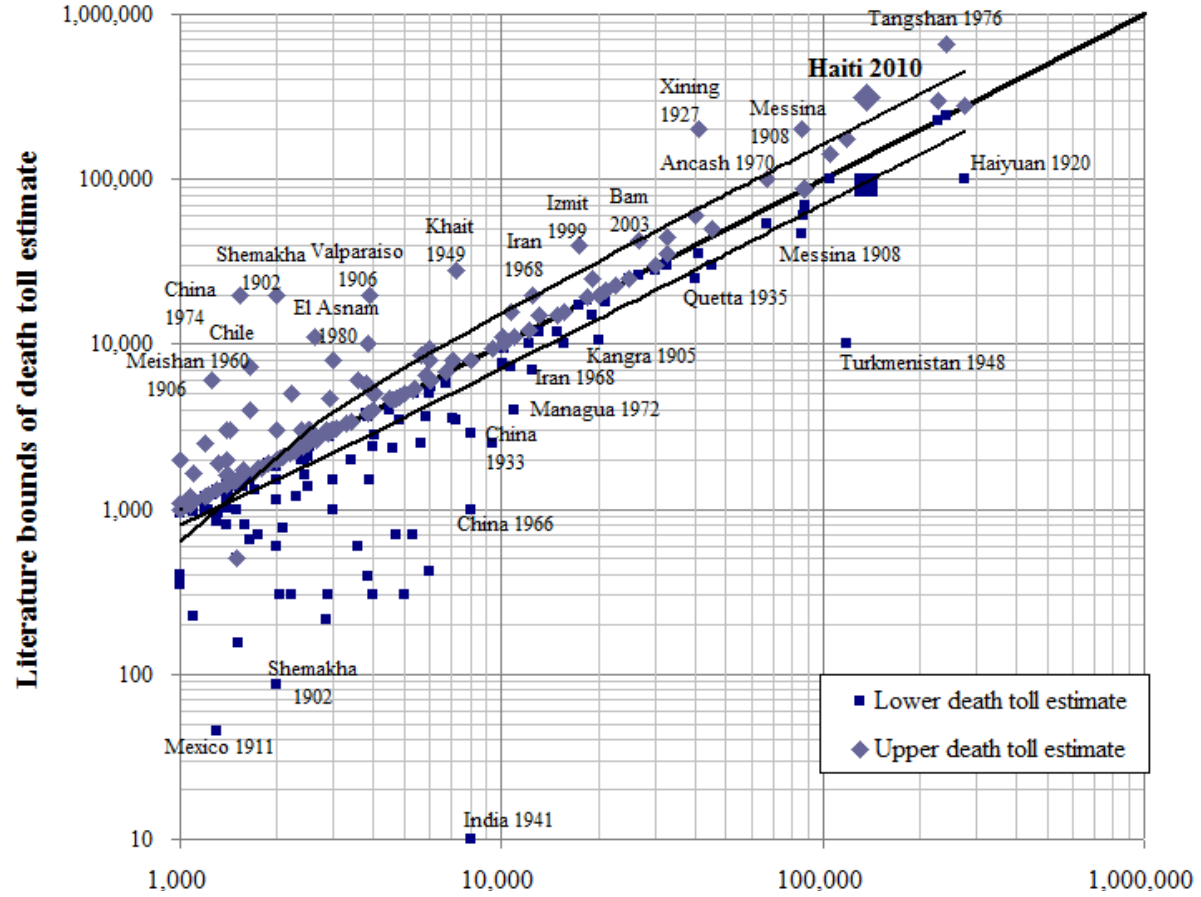

Fig. 2. Overestimates (as shown as diamonds) and underestimates (as shown as blue squares) of historical earthquakes compared with the CATDAT best estimate of death toll (linear line) with a death toll over 1000 since 1900 showing Haiti in bold (after Daniell, 2011 using Daniell, 20032013).

\section{NHESSD}

1, 1913-1942, 2013

Uncovering the 2010 Haiti earthquake death toll

J. E. Daniell et al.

\section{Title Page}

\begin{tabular}{|c|c|}
\hline Abstract & Introduction \\
\hline Conclusions & References \\
\hline Tables & Figures \\
\hline I4 & \\
\hline & \\
\hline Back & Close \\
\hline Full Screen / Esc \\
\hline
\end{tabular}

Printer-friendly Version

Interactive Discussion 